\title{
Critical analysis: use of polymerase chain reaction to diagnose leprosy
}

\author{
Flaviane Granero Maltempe, Vanessa Pietrowski Baldin, Mariana Aparecida Lopes, \\ Vera Lúcia Dias Siqueira, Regiane Bertin de Lima Scodro, Rosilene Fressatti Cardoso, \\ Katiany Rizzieri Caleffi-Ferracioli*
}

Department of Clinical Analysis and Biomedicine, State University of Maringá, Maringá-PR, Brazil

\begin{abstract}
Leprosy is a neglected tropical disease and an important public health problem, especially in developing countries. It is a chronic infectious disease that is caused by Mycobacterium leprae, which has a predilection for the skin and peripheral nerves. Although it has low sensitivity, slit-skin smear (SSS) remains the conventional auxiliary laboratory technique for the clinical diagnosis of leprosy. Polymerase chain reaction (PCR) is a molecular biology technique that holds promise as a simple and sensitive diagnostic tool. In the present study, the performance of two PCR methods, using different targets, PCR-LP and PCR-P, were compared with SSS with regard to leprosy diagnosis in a reference laboratory. M. leprae DNA was extracted from 106 lymph samples of 40 patients who had clinical suspicion of leprosy. The samples were subjected to both PCR techniques and SSS. Amplification of the human $\beta$-globin gene was used as PCR inhibitor control. The specificity of both PCR techniques was $100 \%$, and sensitivity was 0.007 and $0.015 \mu \mathrm{g} / \mathrm{ml}$ for PCR-LP and PCR-P, respectively. No significant difference was found between either the PCR-LP or PCR-P results and SSS results $(p>0.05)$. Although PCR is not yet a replacement for SSS in the diagnosis of leprosy, this technique may be used as an efficient auxiliary tool for early detection of the disease, especially in endemic regions. This strategy may also be useful in cases in which SSS results are negative (e.g., in paucibacillary patients) and cases in which skin biopsy cannot be performed.
\end{abstract}

Uniterms: Leprosy/clinical diagnosis. Polymerase chain reaction/clinical diagnosis use. Mycobacterium leprae.

\begin{abstract}
A hanseníase é uma doença tropical negligenciada e ainda um importante problema de saúde pública, especialmente nos países em desenvolvimento. É uma doença infecciosa crônica causada pelo Mycobacterium leprae, que tem predileção pela pele e nervos periféricos. Embora com baixa sensibilidade, o esfregaço de linfa (SSS) continua sendo o método laboratorial convencional auxiliar no diagnóstico clínico da hanseníase. A biologia molecular representada pela Reação em Cadeia da Polimerase (PCR) trouxe a expectativa de ser uma ferramenta diagnóstica simples e sensível. No presente estudo, o desempenho de dois métodos de PCR usando alvos diferentes, PCR-P e PCR-LP, foi comparado com SSS no diagnóstico da hanseníase em um laboratório de referência. DNA de M. leprae foi extraído de 106 amostras de linfa de 40 pacientes que apresentavam suspeita clínica de hanseníase. As amostras foram submetidas tanto a PCR como SSS. A amplificação do gene humano $\beta$-globina foi usada como controle de inibição da PCR. A especificidade de ambas as técnicas de PCR foi de $100 \%$ e a sensibilidade foi de $0,007 \mu \mathrm{g} / \mathrm{mL}$ e $0,015 \mu \mathrm{g} / \mathrm{mL}$ para a PCR-P e PCR-LP, respectivamente. Não se observou diferença estatística entre os resultados da PCR-LP e PCR-P, quando comparado com SSS (p > 0,05). Apesar de a PCR ainda não substituir o SSS no diagnóstico da hanseníase, esta técnica pode ser usada como ferramenta auxiliar eficiente para a detecção precoce da doença, especialmente em regiões endêmicas. Esta estratégia pode também ser útil nos casos em que os resultados de SSS forem negativos (ex. em pacientes paucibacilares) e em casos onde a biópsia da pele não pode ser realizada.
\end{abstract}

Unitermos: Hanseníase/diagnóstico clínico. Reação em Cadeia da Polimerase/uso em diagnóstico. Mycobacterium leprae.

\footnotetext{
*Correspondence: Prof. K. R. Caleffi-Ferracioli. Laboratório de Bacteriologia Médica, DAB. Universidade Estadual de Maringá. Avenida Colombo, 5.790

- Jardim Universitário, 87020-900 - Maringá - PR, Brasil. Phone: +55 44 30115376, Fax: +55 44 3011-4797. E-mail: katianyrcf@gmail.com
} 


\section{INTRODUCTION}

Leprosy is a neglected tropical disease and still an important public health problem, especially in developing countries. A fast, sensitive, and specific diagnostic method is necessary for earlier detection to prevent disease progression, which can cause irreversible neural damage (Kurabachew Wondimu, Ryon, 1998).

Although leprosy is often diagnosed clinically, slit-skin smear (SSS) remains the laboratorial method of choice for leprosy confirmation and the classification of clinical forms of the disease. A negative SSS result does not necessarily exclude a diagnosis of leprosy. Patients with tuberculoid and indeterminate forms have a low number of bacilli that are present in the skin, referred to as paucibacillary leprosy (Banerjee et al., 2011).

Thus, a more sensitive diagnostic tool is urgently needed for the laboratorial diagnosis of leprosy, especially in such countries as Brazil. More than $90 \%$ of the number of registered cases in the Americas is found in Brazil (Banerjee et al., 2011; Araujo, 2003; WHO, 2008; PAHO, 2007).

The advent of molecular biology brought expectations for the diagnosis of infectious diseases, particularly uncultivable microorganisms in vitro, such as Mycobacterium leprae (Lavania et al., 2011; Millar, Xu, Moore, 1997). Polymerase chain reaction (PCR) has been used to detect $M$. leprae in lymph (Phetsuksiri, et al., 2006), blood (Almeida, 2004), nasal swab (Almeida, 2004), tissue fragment (Phetsuksiri, et al., 2006; Martinez, 2006), and urine (Caleffi et al., 2012, 2010; Parkash et al., 2004) clinical samples.

Different PCR primers have been used to amplify the DNA of M. leprae from clinical samples (Kang, Kim, Lee, 2003). The PCR targets that are used to detect $M$. leprae include genes that encode $36 \mathrm{kDa}$ (known as proline-rich antigen [pra] (Parkash et al., 2004; Torres et al., 2003; Hartskeerl, De Wit, Klatser, 1989), 18 kDa (Chae et al., 2002), $85 \mathrm{kDa}$ (Martinez et al., 2014), and $65 \mathrm{kDa}$ (Plikaytis, Gelber, Shinnick, 1990) protein antigens, 16S rRNA (Phetsuksiri, et al., 2006), and repetitive sequences (Donoghue, Holton, Spigelman, 2001). Cox, Kempsell, Fairclough (1991) and Arnoldi et al. (1992) detected 8.3 bacilli in skin biopsy samples using primers that amplified a specific sequence that was 172 bp from 16S rRNA. Donoghue, Holton, Spigelman (2001) also achieved the selective and specific detection of $M$. leprae in skin biopsy samples using a repetitive and specific region (RLEP) as the target.

In the present study, we compared two PCR protocols for the laboratorial diagnosis of leprosy and compared the results with SSS in patients who attended a reference laboratory.

\section{MATERIAL AND METHODS}

\section{Study population}

Patients from the Northwest of Parana State, which were under clinical diagnosis of leprosy, were selected for the study. The samples collection was carried out at the Laboratory for Teaching and Research in Clinical Analyses (LEPAC), reference center for the diagnosis of leprosy, at the University State of Maringa (UEM), Parana, Brazil, from November 2010 to November 2011. A total of $24.5 \%$ and $75.5 \%$ of patients were classified by SSS as multibacillary and paucibacillary, respectively. No reactive disease cases were investigated during treatment time. The variables age, gender and family history of non-treated and under anti-leprosy therapy were analyzed.

\section{Ethics Statement}

The study was approved by the Ethics Committee of the State University of Maringa, Parana (protocol No. 131/2006). The participation of children underage in the study occurred only after authorization and informed consent of parents or guardians. All participants approved the research protocol and signed the informed consent.

\section{Biological sample}

It was collected 106 lymph samples in different areas of the body from 40 patients: ear lobes $(\mathrm{N}=29)$, elbows $(\mathrm{N}=31)$, knee $(\mathrm{N}=12)$, skin lesions $(\mathrm{N}=33)$ and nodules $(\mathrm{N}=1)$. The collected materials were stored in sterile microtubes containing $30 \mu \mathrm{L}$ of sterile TE $(10 \mathrm{mM}$ Tris$\mathrm{HCl}, 1 \mathrm{mM}$ EDTA, $\mathrm{pH}$ 8.0) and kept at $-20^{\circ} \mathrm{C}$ until use.

\section{DNA extraction in lymph samples}

All lymph samples used for the SSS were submitted to DNA extraction for using in PCR. The M. leprae DNA was extracted using bacterial genomic DNA extraction kit (AxyPrep Minipreo Bacterial Genomic DNA Kit/ Axygen Biosciences) according to the manufacturer's instructions. The extracted DNA samples were stored at $-20{ }^{\circ} \mathrm{C}$ until use.

\section{Specificity and sensitivity of the PCR}

The PCR specificity was evaluated using DNA 
extracted from M. leprae obtained from skin lesion of an armadillo experimentally infected and kindly supplied by the animal laboratory of the Institute Lauro de Souza Lima (São Paulo, Brazil). Reference strains M. tuberculosis H37Rv (ATCC 27.294), M. avium (ATCC 13950), M. kansasii (Lacen / Pr ATCC 0800), M. fortuitum (Lacen / PR), M. szulgai (Lacen / Pr ATCC 1300), M. smegmatis (Lacen/Pr) were also used for specificity test. The DNAs were extracted by phenol-chloroform method previously described by Cardoso et al. (2004).

The PCR sensitivity was determined using total $M$. leprae DNA $(7.48 \mu \mathrm{g} / \mathrm{mL})$, with dilutions ranging from $1: 2(3.74 \mu \mathrm{g} / \mathrm{mL})$ to $1: 2048(4 \mathrm{ng} / \mathrm{mL})$.

\section{PCR assay}

Specific primers for $M$. leprae, P2 (TAACGGAAACTCGGTAAAATCTT) and P3 (GCCGCACCTCATCAAAAAGCTT) for PCR-P and LP1 (TGCATGTCATGGCCTTGAGG) and LP2 (CACCGACGGTACCAGCAGAA) for PCR-LP, which amplify DNA fragments of $172 \mathrm{bp}$ of the gene encoding 16S rRNA (Arnold et al., 1992) and $129 \mathrm{pb}$ of repetitive and specific regions (RLEP) (Kang, Kim, Lee, 2003) were used, respectively.

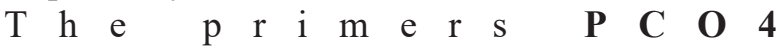
(CAACT TCATCCACGTTCACC) and GH20 (GAAGAGCCAAGGACAGGTAC) that amplify a $268 \mathrm{pb}$ fragment of human $\beta$-globin gene were used as inhibitors sample control according to Rombaldi, Serafini, Mandelli (2008).

The PCR assays were performed using $5 \mu \mathrm{L}$ of template in $20 \mu \mathrm{L}$ of the reaction mixture containing $200 \mathrm{nM}$ primers (Integrated DNA Technologies, USA) and PCR Master Mix (Promega Corporation, USA) according to manufacturer's instructions. The amplifications were carried out in an ABI thermocycler (Mastercycler ${ }^{\circledR}$ gradient PCR, Germany), using the conditions described by Bang et al. (2009) and Donoghue, Holton, Spigelman (2001) for PCR-P and PCR-LP, respectively.

PCR products were separated in $2 \%$ agarose gel electrophoresis in TBE buffer for 1 hour at 100 volts and gel were stained with ethidium bromide $(0.5 \mu \mathrm{g} / \mathrm{mL})$. A 100 base pair DNA Ladder (Invitrogen life technologies, São Paulo, Brazil) was used as a molecular marker. Positive and negative controls were included in all amplification. In the positive controls, $5 \mu \mathrm{L}$ of DNA extracted $(0.15 \mu \mathrm{g} / \mathrm{mL})$ from a skin lesion of armadillo was added to the PCR. For the negative controls, $5 \mu \mathrm{L}$ of TE was added to the PCR.

\section{Data analysis}

Lymph samples that had a fragment of the $268 \mathrm{pb}$ amplified in the PCR-Control (PC04-GH20 primers) were considered without PCR inhibitors, as suggested by Rombaldi, Serafini, Mandelli (2008). Samples were considered positive for $M$. leprae when a single PCR product of $172 \mathrm{bp}$ and/or $129 \mathrm{pb}$ was observed by PCR-P and PCR-LP, respectively. When the PCR-Control showed to be negative, it was repeated using DNA templates diluted to 1:2. Patients' samples were considered negative when no amplification by specific primers was observed and amplification by PCR-Control was positive.

Data was analyzed using the McNemar test (software BioStat 5.0). The results were considered significant for $\mathrm{p}<0.05$.

\section{RESULTS}

A total of 40 patients participated in the study (17 females [42.5\%] and 23 males [57.5\%]). The average age of the patients with leprosy was 53.15 years (range, 7-85 years). Among the patients, $30(75 \%)$ were in the diagnosis phase, and $10(25 \%)$ had clinically confirmed leprosy and were undergoing treatment.

Both PCR-P and PCR-LP showed 100\% specificity for M. leprae. No amplification was observed using DNA that was extracted from $M$. tuberculosis, M. avium, $M$. kansasii, M.fortuitum, M. szulgai, or M. smegmatis as the template. PCR-P and PCR-LP detected $M$. leprae DNA up to $1: 512(15 \mathrm{ng} / \mathrm{mL})$ and $1: 1024(7 \mathrm{ng} / \mathrm{mL})$, respectively.

The PCR-P, PCR-LP, and SSS results of the patient samples are described in Table I. All of the patients who were undergoing treatment had positive results in both PCR assays and the SSS assay. One lymph sample (1.43\%) of a patient who was in the diagnosis phase had a negative SSS result and positive PCR-LP result.

No significant difference was found between the SSS results and PCR-P $(p=0.134)$ or PCR-LP $(p=1.000)$ results. PCR-LP and PCR-P had comparable performance in detecting M. leprae DNA in lymph samples ( $p=0.074$; Table I).

The PCR-Control technique presented initial inhibition in 19 of 106 (17.92\%) of the lymph samples. After dilution of the DNA template (1:2), inhibition persisted in 15 of $106(14.15 \%)$ of the analyzed samples.

The lymph that was obtained from ear lobe and skin lesions showed greater positivity in the PCR-P and PCRLP assays in 6 of 7 samples ( $86 \%$ ) and 7 of 7 samples $(100 \%)$, respectively (data not shown). 
TABLE I - Comparison of the Slit Skin Smear (SSS) with PCR-LP and PCR-P results in leprosy patients

\begin{tabular}{|c|c|c|c|c|c|}
\hline \multirow{2}{*}{ PCR assays } & \multicolumn{2}{|c|}{ PCR** } & \multicolumn{2}{|c|}{ SSS** } & \multirow{2}{*}{$p$} \\
\hline & $+(\%)$ & $-(\%)$ & $+(\%)$ & $-(\%)$ & \\
\hline PCR-LP & $22(24.17)$ & $69(75.83)$ & $21(23.08)$ & $70(76.92)$ & 1.000 \\
\hline PCR-P & $17(18.68)$ & $74(81.32)$ & & & 0.134 \\
\hline
\end{tabular}

$\mathrm{p}=0.074$, McNemar test, PCR- LP vs PCR- P. **The samples with inhibitors, in the PCR assay, were excluded (15/106; 14.15\%).

\section{DISCUSSION}

The transmission of leprosy still occurs despite the availability of effective treatment. It is a disease with a long incubation time, and the symptoms are difficult to recognize, mainly in the early stage of the disease. Selfhealing occurs in a large number of infected individuals, and many patients with early signs are unaware that they are suffering from leprosy, thus often delaying clinical diagnosis (Banerjee et al., 2010). Clinical diagnosis is possible only when the patient is symptomatic, exhibiting skin lesions or presenting the clinical criteria of cardinal signs of leprosy (Martinez et al., 2006). Polymerase chain reaction may be an important tool for helping diagnose leprosy in cases in which clinical findings and SSS are inconclusive, such as with pure neural leprosy, paucibacillary cases, and atypical clinical presentation (Martinez et al., 2014).

An early laboratory diagnosis of leprosy still presents difficulties. The SSS technique shows low sensitivity in detecting acid-fast bacilli, and a trained professional must perform the smear readings. Because a negative SSS result does not necessarily exclude a diagnosis of leprosy, an assay with higher sensitivity is needed for the detection of M. leprae.

More male than female patients participated in the present study. There was a predominance of economically active population, with an average age of 53.15 years, which is consistent with the existing literature (Gomes, Pontes, Gonçalves, 2005).

The specificity of PCR-P and PCR-LP in the detection of $M$. leprae was comparable to the specificity reported by Bang et al. (2009) and Donoghue, Holton, Spigelman (2001). With regard to sensitivity, PCR-LP had a higher ability to detect DNA of M. leprae in lymph samples. According to Donoghue, Holton, Spigelman (2001), the higher sensitivity of PCR-LP may be associated with amplification of a 28-repeat fragment in the genome of M. leprae.

Higher positivity in detecting DNA of M. leprae was found in lymph samples that were collected from ear lobe and skin lesions, with comparable performance between PCR-P and PCR-LP. These data reinforce the need to collect lymph samples from cold areas of the body (e.g., the ears, elbows, knees) to diagnose leprosy, as recommended by the Brazilian Ministry of Health (Brasil, 2014).

No significant difference was found between the PCR-LP or PCR-P results and SSS results $(p>0.05)$. Although no significant results were observed, the use of PCR as an additional diagnosis tool was extremely beneficial for one patient. The positive PCR results allowed an early diagnosis of leprosy, prompting the initiation of treatment. An analysis with a larger number of leprosy patients may reveal higher PCR sensitivity compared with SSS, as demonstrated by other studies (Bang et al., 2009; Martelli, Stefani, Penna 2002).

The use of control primers (PC04-GH20) that are specific for human DNA (human $\beta$-globin) showed good performance in determining the quality of the sample that was subjected to specific PCR. A significant percentage of PCR inhibition was observed in the samples (19 of 106 [17.92\%]). Some substances, such as nitrate, urea, proteins, blood, and even high levels of human genomic DNA, have been shown to prevent amplification in the PCR assay (Martinez et al., 2006; Toye, Woods, Bobrowska, 1998). In the present study, all of the samples that showed inhibition in the PCR-Control assay were retested with 1:2 diluted extracted samples. This procedure showed improvement in detecting $M$. leprae in four additional lymph samples. However, 15 of 106 (14.15\%) lymph samples continued to show PCR inhibition. Importantly, dilution of the extracted sample needs to be considered because diluted inhibitors will consequently dilute $M$. leprae DNA and can make the detection of specific DNA more difficult in some cases.

Generally, both PCR assays had sufficient sensitivity to detect some $M$. leprae bacilli which could not otherwise be detected by SSS. Detecting M. leprae is crucial for diagnosing some cases of leprosy and correctly classifying patients for treatment, and PCR is expected to make a precise diagnosis (Sugita, 2001). Concern arises regarding the classification of patients into paucibacillary or multibacillary leprosy to guide therapy. Currently, negative SSS results indicate paucibacillary leprosy, and positive 
results indicate multibacillary leprosy. This classification should be reconsidered if PCR is implemented in routine laboratory practice.

Importantly, nucleic acids that are detected by PCR in lymph samples do not necessarily indicate the presence of viable M. leprae (Speers, 2006). A positive result by PCR, as by SSS, in patients' samples can spend variable time to become negative after the start of antimicrobial therapy. Thus, the use of PCR to detect $M$. leprae is a promising tool during the stage of leprosy diagnosis.

Notably, PCR may be an important adjunct tool in the diagnosis of leprosy, but it still cannot replace conventional laboratory methods. In developed countries, this technique has been used as an aid in the diagnosis of difficult cases of leprosy (Martelli, Stefani, Penna, 2002). Over the years, this method has become more accessible to various laboratories and can be especially useful in cases in which SSS results are negative and in cases in which skin biopsy cannot be performed, such as with atypical locations of lesions (Katoch, Lavania, Chauhan, 2010).

The present study compared SSS and PCR techniques using lymph samples, which is a conventional biological material that is routinely collected for the laboratory diagnosis of leprosy. One limitation of the present study, however, was the relatively low number of clinical samples and primers tested. Nonetheless, PCR-LP showed good sensitivity concomitantly with the SSS assay. Further studies are necessary to standardize and optimize PCR techniques in the laboratory diagnosis of leprosy.

\section{CONCLUSION}

The present study found that PCR can be beneficial as an efficient auxiliary tool, especially in endemic regions, for leprosy diagnosis in conjunction with SSS, although it cannot replace the SSS assay and still remains inaccessible to many laboratories with few financial resources. Polymerase chain reaction can also be useful for patients with negative SSS findings and for patients in whom skin biopsy cannot be performed.

\section{REFERENCES}

ALMEIDA, E.C.; MARTINEZ, N.A.; MANIERO, V.C.; SALES, A.M.; DUPPRE, N.C.; SARNO, E.N.; SANTOS, A.R.; MORAES, M.O. Detection of Mycobacterium leprae DNA by polimerase chain reaction in the blood and nasal secretion of brazilian husehold contacts. Mem. Inst. Oswaldo Cruz, v.99, n.5, p.509-511, 2004.
ARAÚJO, M.G. Hanseníase no Brasil. Rev. Soc. Bras. Med. Trop., v.36, n.3, p.373-382, 2003.

ARNOLD, J.; SCHLUTER, C.; DUCHROW, M.; HUBNER, L; ERNST, M.; TESKE, A.; FLAD, H.D.; GERDES, J.; BOTTGER, E.C. Species-specific assessment of Mycobacterium leprae in skin biopsies by in situ hybridization and polymerase chain reaction. Lab. Investig., v.66, n.5, p.618-623, 1992.

BANERJEE, S.; BISWAS, N.; DAS, N.K.; SIL, A.; HASANOOR, R.A.H.; DASGUPTA, S.; KANTI, D.P.; BHATTACHARYA, B. Diagnosing leprosy: revisiting the role of the slit-skin smear with critical analysis of the applicability of polymerase chain reaction in diagnosis. Int. J. Dermatol., v.50, n.12, p.1522-1527, 2011.

BANERJEE, S.; SARJAR, K.; GUPTA, S.; MAHAPATRA, P.S.; GUPTA, S.; GUHA, S., BANDHOPADHAYAY, D., GHOSAL, C.; PAINE, S.K.; DUTTA, R.N.; BISWAS, N.; BHATTACHARYA, B. Multiplex PCR technique could be an alternative approach for early detection of leprosy among close contacts: a pilot study from India. BMC Infec. Dis., v.10, p.252, 2010.

BANG, P.D.; SUZUKI, K.; PHUONG, L.E.T.; CHU, T.M.; ISHII, N.; KHANG, T.H. Evaluation of polymerase chain reaction-based detection of Mycobacterium leprae for the diagnosis of leprosy. J. Dermatol., v.36, n.5, p.269-276, 2009.

BRASIL. Ministério da Saúde. Secretaria de Vigilância em Saúde. Departamento de Vigilância Epidemiológica. Guia de procedimentos técnicos Baciloscopia em Hanseníase. Brasília: Ministério da Saúde, 2010. (Série A. Normas e Manuais Técnicos). Available at: $<$ http://bvsms.saude. gov.br/bvs/publicacoes/guia_procedimentos_tecnicos corticosteroides_hanseniase.pdf $>$. Accessed on: 09 Dec. 2014.

CALEFFI, K.R.; HIRATA, R.D.C.; HIRATA, M.H.; CALEFFI, E.R.; PEIXOTO, P.R.; SPOSITO, F.L.E.; CARDOSO, R.F. Evaluation of $85 \mathrm{~A}-\mathrm{C}$ intergenic region $\mathrm{PCR}$ primers for detection of Mycobacterium leprae DNA in urine samples. Int. J. Dermatol., v.49, n.6, p.715-723, 2010.

CALEFFI, K.R.; HIRATA, R.D.C.; HIRATA, M.H.; CALEFFI, E.R.; SIQUEIRA, V.L.; CARDOSO, R.F. Use of the polymerase chain reaction to detect Mycobacterium leprae in urine. Braz. J. Med. Biol. Res., v.45, n.2, p.153-157, 2012. 
CARDOSO, F.C.; COOKSEY, R.C.; MORLOCK, G.P.; BARCO, P.; CECON, L.; FORESTIERO, F.; LEITE, C.Q.; SATO, D.N.; SHIKAMA, M.L.; MAMIZUKA, E.M.; HIRATA, R.D.; HIRATA, M.H. Screening and characterization of mutations in isoniazid resistant Mycobacterium tuberculosis isolates obtained in Brazil. Antimicrob. Agents Chemother, v.48, n.9, p.3373-3381, 2004.

CHAE, G.T.; KIM, M.J.; KANG, T.J.; LEE, S.B.; SHIN, H.K.; KIM, J.P.; KO, Y.H.; KIM, N.H. DNA-PCR and RT-PCR for the 18-kDa gene of Mycobacterium leprae to assess the efficacy of multi-drug therapy for leprosy. J. Med. Microbiol., v.51, n.5, p.417-422, 2002.

COX, R.A.; KEMPSELL, K.; FAIRCLOUGH, L. The $16 \mathrm{~S}$ ribosomal RNA of Mycobacterium leprae contains a unique sequence which can be used for identification by the polymerase chain reaction. J. Med. Microbiol., v.35, n.5, p.284-290, 1991.

DONOGHUE, H.D.; HOLTON, J.; SPIGELMAN, M. PCR primers that can detect low levels of Mycobacterium leprae DNA. J. Med. Microbiol., v.50, n.2, p.177-182, 2001.

GOMES, C.C.D.; PONTES, M.M.A.; GONÇALVES, H.S. Clinical and epidemiological profile of patients diagnosed with leprosy in a reference center in the northeast of Brazil. An. Bras. Dermatol., v.80, n.3, p.283-288, 2005.

HARTSKEERL, R.A.; DE WIT, M.Y.; KLATSER, P.R. Polymerase chain reaction for the detection of Mycobacterium leprae. J. Gen. Microbiol., v.135, p.23572364, 1989.

KANG, T.J.; KIM, S.K.; LEE, S.B. Comparison of two different PCR amplification products (the $18-\mathrm{kDa}$ protein gene vs. RLEP repetitive sequence) in the diagnosis of Mycobacterium leprae. Clin. Exp. Dermatol., v.28, n.4, p.420-424, 2003.

KATOCH, V.M.; LAVANIA, M.; CHAUHAN, D.S. Recent advances in molecular biology of leprosy. Ind. J. Lep., v.79, n.2/3, p.151-166, 2010.

KURABACHEW, M.; WONDIMU, A.; RYON, J.J. Reverse transcription-PCR detection of Mycobacterium leprae in clinical specimens. J. Clin. Microbiol., v.36, n.5, p.13521356, 1998.
LAVANIA, M.; KATOCH, K.; SHARMA, R.; DAS, R.; GUPTA, A.K.; CHAUHAN, D.S., KATOCH, V.M. Molecular typing of Mycobacterium leprae strains from northern India using short tandem repeats. Ind. J. Med. Res., v.133, n.6, p.618-626, 2011.

MARTELLI, C.M.T.; STEFANI, M.M.A.; PENNA, G.O. Endemias e epidemias brasileiras, desafios e perspectivas de investigação científica: hanseníase. Rev. Bras. Epidemiol., v.5, n.3, p.273-285, 2002.

MARTINEZ, N.A.; BRITTO, C.F.P.C.; NERY, J.A.C.; SAMPAIO, E.P.; JARDIM, M.R.; SARNO, E.N.; MORAES, M.O. Evaluation of real-time and conventional PCR targeting complex 85 genes for detection of Mycobacterium leprae DNA in skin biopsy samples from patients diagnosed with leprosy. J. Clin. Microbiol., v.44, n.9, p.3154-3159, 2006.

MARTINEZ, A.N.; TALHARI, C.; MORAES, M.O.; TALHARI, S. PCR-based techniques for leprosy diagnosis: from the laboratory to the clinic. PLoS Negl. Trop. Dis., v.8, n.4, art.e2655, p.1-8, 2014.

MILLAR, B.C.; XU, J.; MOORE, J.E. Molecular diagnostics of medically important bacterial infections. Curr. Issues Mol. Biol., v.9, n.1, p.21-39, 1997.

PAN AMERICAN HEALTH ORGANIZATION. PAHO. Situation Report: Leprosy in the Americas. Washington: Pan American Health Organization, 2007. Available at: $<$ http:// www1.paho.org/English/AD/DPC/CD/lep-sit-reg-2007. pdf $>$. Accessed on: 06 Jun. 2016.

PARKASH, O.; SINGH, H.B.; RAI, S.; PANDEY, A.; KATOCH, V.M.; GIRDHAR, B.K. Detection of Mycobacterium leprae DNA for $36 \mathrm{kDa}$ protein in urine from leprosy patients: a preliminary report. Rev. Inst. Med. Trop. São Paulo, v.46, n.5, p.275-277, 2004.

PHETSUKSIRI, B.; RUDEEANEKSIN, J.; SUPAPKUL, P.; WACHAPONG, S.; MAHOTARN, K.; BRENNAN, P.J. A simplified reverse transcriptase PCR for rapid detection of Mycobacterium leprae in skin specimens. FEMS Immunol. Med. Microbiol., v.48, n.3, p.319-328, 2006.

PLIKAYTIS, B.B.; GELBER, R.H.; SHINNICK, T.M. Rapid and sensitive detection of Mycobacterium leprae using a nested-primer gene amplification assay. J. Clin. Microbiol., v.28, n.9, p.1913-1917, 1990. 
ROMBALDI, R.L.; SERAFINI, E.P.; MANDELLI, J. Transplacental transmission of human Papillomavirus. Virol. J., v.5, n.106, p.1-14, 2008.

SPEERS, D.J. Clinical applications of molecular biology for infectious diseases. Clin. Biochem. Rev., v.27, n.1, p.39$51,2006$.

SUGITA, Y. PCR in leprosy. Nihon Hansenbyo Gakkai Zasshi, v.70, n.1, p.3-13, 2001.

TORRES, P.; CAMARENA, J.J.; GOMEZ, J.R.; NOGUEIRA, J. M.; GIMENO, V.; NAVARRO, J.C.; OLMOS, A. Comparison of PCR mediated amplification of DNA and the classical methods for detection of Mycobacterium leprae in different types of clinical samples in leprosy patients and contacts. Lep. Rev., v.74, n.1, p.18-30, 2003.
TOYE, B.; WOODS, W.; BOBROWSKA, M. Inhibition of PCR in genital and urine specimens submitted for Chlamydia trachomatis testing. J. Clin. Microbiol., v.36, n.8, p.23562358, 1998.

WORLD HEALTH ORGANIZATION. WHO. Report leprosy, global situation. Week. Epidemiol. Rec., v.33, p.293-300, 2008.

Received for publication on $17^{\text {th }}$ December 2014 Accepted for publication on $5^{\text {th }}$ August 2015 
